\title{
PENGGUNAAN CITRA HIMPUNAN JULIA SEBAGAI CITRA SAMPUL UNTUK MENYEMBUNYIKAN CITRA RAHASIA
}

\author{
Janoe Hendarto \\ Departemen Ilmu Komputer dan Elektronika \\ Fakultas Matematika dan Ilmu Pengetahuan Alam \\ Universitas Gadjah Mada \\ email: jhendarto@ugm.ac.id
}

\begin{abstract}
Abstraksi
Steganografi dengan metode fraktal (fractal steganography) adalah teknik menyembunyikan informasi atau pesan, yang dapat berupa citra rahasia, dalam suatu citra sampul (cover image) yang berupa citra fraktal (fractal image). Dalam penelitian ini digunakan citra fraktal matematis yaitu citra himpunan Julia dari fungsi komplek $z^{2}-c$, dengan memanfaatkan sifat-sifat fraktalnya yaitu antara lain sensitif terhadap nilai awal, kesamaan diri dan iteratif.

Pertama, dibahas bagaimana menyembunyikan citra rahasia dalam suatu citra sampul yaitu citra himpunan Julia dari fungsi komplek $z^{2}$ - c dengan nilai c dijadikan salah satu komponen dari kunci(key) dan juga nggunakan manipulasi warna (RGB) dari citra sampul, suatu pesan berupa citra rahasia yang sudah dikonversi dalam betuk matrik biner 0,1 dapat disembunyikan sehingga menghasilkan citra stego (stego image) yang secara visual sama dengan citra sampulnya dan diharapkan tahan terhadap serangan. Kemudian, dibuat program komputer yang mampu menyembunyikan dan mengambil kembali citra rahasia pada citra sampul himpunan. Dari analisis hasil program komputer yang dibuat, perbandingan antara citra sampul dan citra stego berukuran $512 \times 512$ pixel, didapat bahwa rata-rata RMSE 0,2305 dan rata-rata PSNR 60,88 db dari 12 set data uji, hal ini menunjukkan bahwa kedua citra sangat mirip sehingga sulit dibedakan mana citra yang memuat citra rahasia dengan ukuran citra rahasia paling besar $128 x 85$ pixel atau 261.120 bits. Waktu proses penyembunyian citra rahasia rata-rata 1,626 detik (tidak termasuk waktu pembuatan citra sampul) sedangkan waktu proses pengambilan kembali citra rahasia rata-rata 4,526 detik.
\end{abstract}

Kata kunci: Steganografi fraktal, Himpunan Julia, Citra sampul, Citra rahasia, Citra stego.

\begin{abstract}
Fractal steganography is a technique to hide information or messages, which can be a secret image, in the fractal image as a cover image. In this research, the image of Julia's set of the complex functions $z^{2}-c$ are used, with utilizing the properties of fractals, which are sensitive to initial value, self-similarity and iterative.

First, it discussed how to hide the secret image in a cover image, the image of the Julia set of the complex function $z 2-c$ with the value $c$ being one of the components of the key and also using color manipulation (RGB) of the cover image, the secret image that has been converted in the form of a binary matrix 0,1 can be hidden so as to produce a stego image which is visually the same as the cover image and is expected to be resistant to attacks. Then, the computer program is created that is able to hide and retrieve the secret image in the cover image of Julia set. From the analysis of the results of the computer program, the comparison between the cover image and the stego image with $512 \times 512$ pixels, it is found that the average of RMSE is 0.2305 and the average of PSNR is $60.88 \mathrm{db}$ from 12 data sets, this shows that the two images are very similar so that it is difficult to distinguish which image contains a secret image with the largest secret image size of 128x85 pixels or 261,120 bits. The average time for hiding the secret image is 1.626 seconds (not including the time for making the cover image), while the time for retrieving the secret image is 4.526 seconds on average.
\end{abstract}

Keywords: Fractal steganography, Julia set, Cover image, Secret image, Stego image. 


\section{PENDAHULUAN}

Menyembunyikan citra rahasia ke dalam gambar himpunan Julia dengan metode fraktal adalah termasuk steganografi fraktal (fractal steganography) yaitu teknik menyembunyikan informasi dalam suatu citra sampul (cover image) yang berupa citra fraktal (fractal image) dan memanfaatkan sifat-sifat fraktalnya yaitu antara lain sensitif terhadap nilai awal, kesamaan diri dan iteratif (Agaian dan Susmilch, 2006).

Kelebihan citra fraktal sebagai citra sampul adalah citra fraktal dapat dikodekan, yaitu dicari sistem fungsi iterasinya, dan juga citra fraktal sensitif terhadap nilai parameter dari sistem fungsi iterasinya (bersifat kaotik). Pada penelitian sebelumnya, telah dilakukan penyembunyian pesan berupa teks pada citra sampul himpunan Julia, akan tetapi ukuran pesan teksnya sangat terbatas dikarenakan ragam citra himpunan Julianya masih belum begitu banyak dan metodenya belum optimal (Hendarto, 2019). Untuk menyembunyikan citra rahasia diperlukan metode yang mampu menyembunyikan data biner dengan ukuran lebih besar.

Pada penelitian ini dielaborasi dan dikaji (a). Bagaimana menyembunyikan sebuah citra rahasia dalam suatu citra sampul berupa citra himpunan Julia. (b). Bagaimana efisiensi dari metode penyembunyiannya, dengan menentukan ukuran maksimal citra rahasia yang dapat disembunyikan, dan kualitas dari citra hasil (citra stego). Kemudian bagaimana pengaruh bentuk citra sampul, yaitu citra himpunan Julia terhadap efisiensi metode penyembunyiannya. (c). Bagaimana program komputer untuk menyembunyikan citra rahasia dalam citra sampul berupa citra himpunan Julia tersebut dan mengambil kembali citra rahasia dari citra hasil.

Tabel 1. Hasil tinjauan pustaka tentang steganografi menggunakan dengan metode fraktal

\begin{tabular}{|c|c|c|}
\hline Peneliti & Topik Penelitian, Metode yang digunakan & Kekurangan/kelemahan \\
\hline $\begin{array}{l}\text { Agaian dan } \\
\text { Susmilch, } 2006\end{array}$ & $\begin{array}{l}\text { Algoritme global untuk menyusun citra fraktal } \\
\text { dengan transformasi Affine, kemudian membahas } \\
\text { langkah-langkah global untuk menyembunyikan } \\
\text { dan mengambil informasi pada citra fraktal berupa } \\
\text { citra pohon dan citra Voncoch, juga dibahas } \\
\text { steganografi pada citra Lenna dan citra Rose. }\end{array}$ & $\begin{array}{l}\text { Pesan yang dapat } \\
\text { disembunyikan ukurannya } \\
\text { relatif kecil yaitu } 3500 \text { bit, } \\
\text { sedangkan steganografi } \\
\text { pada citra Lenna dan citra } \\
\text { Rose RMSE nya masih } \\
\text { agak tinggi. }\end{array}$ \\
\hline $\begin{array}{l}\text { Kiani, K. dan } \\
\text { Soleimani, } \\
\text { M.A.V., } 2010\end{array}$ & $\begin{array}{l}\text { Pendekatan baru penyembunyian data otentikasi } \\
\text { ( digital watermarking ) menggunakan fraktal dan } \\
\text { chaos. Menggunakan pengkodean fraktal (SFI) } \\
\text { untuk menganalisis metode watermarking yang } \\
\text { diusulkan. }\end{array}$ & $\begin{array}{l}\text { Akurasi pesan yang } \\
\text { disembunyikan dapat } \\
\text { diambil kembali sekitar } \\
80 \% \text { dan citra sampul yang } \\
\text { digunakan citra keabuan. }\end{array}$ \\
\hline $\begin{array}{l}\text { Zhang, H. dkk. , } \\
2011\end{array}$ & $\begin{array}{l}\text { Mengusulkan skema steganografi berbasis citra } \\
\text { fraktal, yaitu citra himpunan Julia, yang diharapkan } \\
\text { lebih tahan terhadap serangan. Algoritme untuk } \\
\text { ekstraksi informasi menggunakan yang hampir } \\
\text { sama dengan algoritme untuk menyembunyikan } \\
\text { informasi. }\end{array}$ & $\begin{array}{l}\text { RMSE dari citra stegonya } \\
\text { masih tinggi, secara visual } \\
\text { untuk menyembunyikan } \\
\text { pesan } 32000 \text { bit citra } \\
\text { stegonya sangat terlihat } \\
\text { beda sekali. }\end{array}$ \\
\hline $\begin{array}{l}\text { Patel, H.N. dkk., } \\
2017\end{array}$ & $\begin{array}{l}\text { Mengusulkan metode steganografi fraktal berbasis } \\
\text { palet warna dengan citra sampulnya adalah citra } \\
\text { himpunan Julia, proses penanaman bit dari pesan } \\
\text { menggunakan pengurutan terhadap palet warna } \\
\text { berdasarkan nilai iluminasi dari pikselnya. }\end{array}$ & $\begin{array}{l}\text { Yang disembunyikan } \\
\text { adalah citra berukuran } \\
\text { 90x90 dengan PSNR rata- } \\
\text { rata } 59 .\end{array}$ \\
\hline $\begin{array}{l}\text { Gupta, R. dkk. } \\
2018\end{array}$ & $\begin{array}{l}\text { Skema pengkodean citra digital dalam steganografi } \\
\text { menggunakan teknik fraktal dalam meningkatkan } \\
\text { efisiensi algoritmenya, dengan menggunakan sifat } \\
\text { kesamaan diri dari citra fraktal dan transformasi } \\
\text { region, percobaan dilakukan terhadap citra sampul } \\
\text { warna dan keabuan. }\end{array}$ & $\begin{array}{l}\text { PSNR rata-ratanya } 56,45 \\
\text { db masih bisa } \\
\text { ditingkatkan. }\end{array}$ \\
\hline Hosam, O., 2018 & $\begin{array}{l}\text { Steganografi untuk menyembunyikan bitcoin ke } \\
\text { dalam citra pohon fraktal. Penyisipan kunci } \\
\text { dilakukan dengan menggambar pohon fraktal. } \\
\text { Sedangkan proses ekstraksi dilakukan dengan } \\
\text { menerapakan prosedur pemrosesan citra fraktal. }\end{array}$ & $\begin{array}{l}\text { Untuk pesan yang } \\
\text { disembunyikan berukuran } \\
40000 \text { bit menghasilkan } \\
\text { error ekstrasi sebesar } \\
0,987 \text {. }\end{array}$ \\
\hline
\end{tabular}




\begin{tabular}{|c|c|c|}
\hline $\begin{array}{l}\text { Kaur, G. dan } \\
\text { Verma, } \\
\text { S.K. ,2018 }\end{array}$ & $\begin{array}{l}\text { Teknik watermarking yang mengkombinasikan } \\
\text { RSA dan pengkodean citra dapat mengatasi } \\
\text { kelemahan dari metode watermarking sebelumnya. } \\
\text { Algoritme dapat meningkatkan keamanan terhadap } \\
\text { serangan seperti pemotongan, pemberian noise acak } \\
\text { dan kompresi JPEG }\end{array}$ & $\begin{array}{l}\text { Citra yang disembunyikan } \\
\text { citra khusus watermark } \\
\text { dan citra sampulnya bukan } \\
\text { himpunan Julia. }\end{array}$ \\
\hline $\begin{array}{l}\text { Mohammed, } \\
\text { N.Q. dkk. , } 2018\end{array}$ & $\begin{array}{l}\text { Kelemahan dan keterbatasan citra himpunan Julia } \\
\text { sebagai citra sampul dalam menyembunyikan } \\
\text { informasi, kemudian mengusulkan langkah-langkah } \\
\text { untuk mengatasi kelemahan tersebut yaitu dengan } \\
\text { menentukan jangkauan nilai parameter dari } \\
\text { himpunan Julia sehingga diharapkan lebih aman. }\end{array}$ & $\begin{array}{l}\text { Yang disembunyikan } \\
\text { pesan teks, belum } \\
\text { membahas bagaimana } \\
\text { menyembunyikan citra } \\
\text { rahasia pada citra sampul } \\
\text { himpunan Julia. }\end{array}$ \\
\hline $\begin{array}{l}\text { Hendarto, J., } \\
2019\end{array}$ & $\begin{array}{l}\text { Melakukan penyembunyian pesan berupa teks pada } \\
\text { beberapa macam citra sampul himpunan Julia } \\
\text { berikuran 500x500 pixel, dengan ukuran pesan } \\
\text { teksnya sangat terbatas yaitu maksimum } 80.000 \\
\text { bits, dikarenakan metodenya belum optimal. }\end{array}$ & $\begin{array}{l}\text { Yang disembunyikan } \\
\text { pesan teks, metodenya } \\
\text { belum optimal, pesan yang } \\
\text { disembunyikan berukuran } \\
\text { kecil. }\end{array}$ \\
\hline
\end{tabular}

Dari penelitian-penelitian di atas, sebagian besar membahas penyembunyian informasi berupa pesan teks, data otentikasi (watermark) dan bitcoin, dan hanya menggunakan satu atau dua macam citra sampul/citra fraktal. Pada penelitian ini akan dibahas penyembunyian sebuah citra rahasia menggunakan citra fraktal himpunan Julia sebagai citra sampulnya dan akan dicari citra himpunan Julia yang mampu menyembunyikan ukuran citra rahasia semaksimal mungkin dengan mempertahankan kualitas dari citra hasilnya (citra stego).

\section{METODE PENELITIAN}

Langkah-langkah yang dilakukan dalam penelitian ini adalah:

1. Studi pustaka, mulai dari referensi buku hingga mempelajari paper-paper mengenai steganografi secara umum dan steganografi dengan metode fraktal.

2. Analisis permasalahan dan analisis terhadap metode/algoritme steganografi dengan menggunakan metode fraktal, terutama permasalahan menyembunyikan citra rahasia pada citra sampul himpunan Julia.

3. Perancangan aplikasi penyembunyian citra rahasia dalam citra sampul berupa citra himpunan Julia dengan metode fraktal, secara garis besar langkah-langkah penyembunyian dan pengambilan citra rahasia dengan metode fraktal dapat dinyatakan dengan diagram alir pada Gambar 1 .

4. Mengimplementasikan aplikasi dalam bentuk program, dengan menggunakan bahasa pemrograman Delphi.

5. Menguji program aplikasi penyembunyian dan pengambilan citra rahasia dengan metode fraktal dengan menggunakan data uji yaitu beberapa citra sampul himpunan Julia dan beberapa citra rahasia yang akan disembunyikan, kemudian dihitung Root Mean Square Error (RMSE) dan Peak Signal to Noise Ratio (PSNR) serta waktu prosesnya dari citra hasil steganografi. 


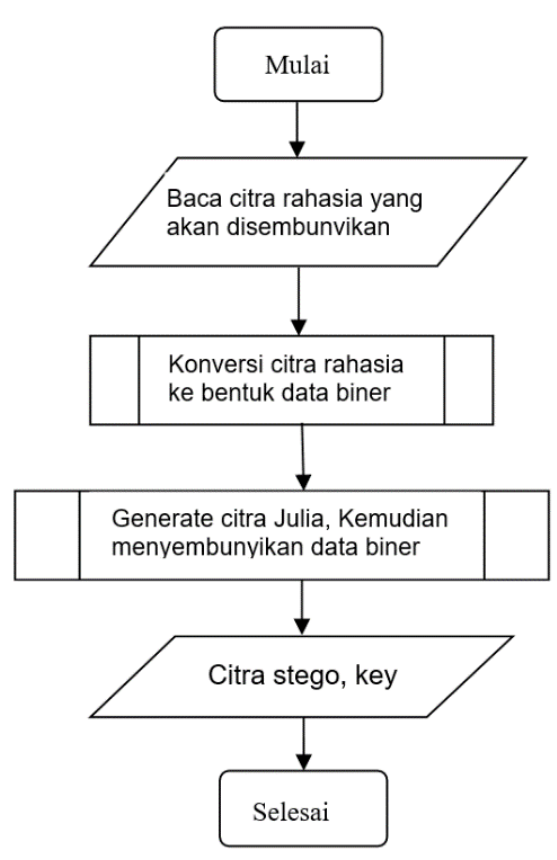

Proses Penyembunyian citra rahasia

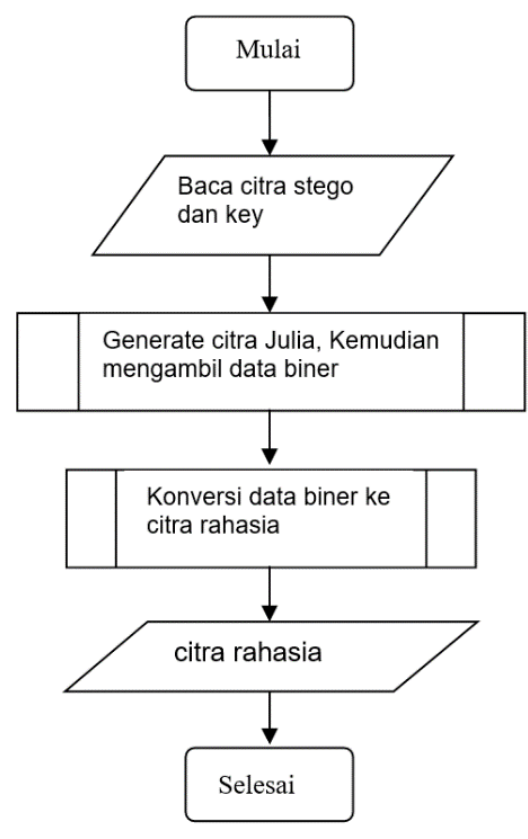

Proses Pengambilan citra rahasia

Gambar 1. Diagram alir penyembunyian dan pengambilan citra rahasia

\section{HASIL DAN PEMBAHASAN}

Pertama akan disiapkan citra sampul (cover image) yang berupa gambar himpunan Julia, serta menyiapkan data uji beberapa citra rahasia yang akan disembunyikan, kemudian dirancang algoritme dan program komputer untuk menyembunyikan citra rahasia dan mengambil kembali citra rahasia dengan metode fraktal dan akhirnya dianalisis hasil program komputernya.

\section{A. Penyiapan Citra Sampul dan Citra Rahasia}

Citra sampul yang digunakan dalam penelitian ini adalah citra fraktal berukuran $512 \times 512$ pixel, yaitu gambar himpunan Julia dari fungsi komplek $\mathrm{z}^{2}-\mathrm{c}$ dengan berbagai nilai c yang dapat dicari melalui gambar himpunan Mandelbrot dari fungsi komplek yang sama, contoh citra himpunan Julia yang digunakan sebagai citra sampul dapat dilihat pada Gambar 2. Sedangkan untuk citra rahasia yang akan disembunyikan berupa 6 citra warna yaitu citra Lenna (a), citra Barbara (b), citra Pepper(c), citra Baboon(d), citra UGM(e) dan citra Sailboat(f) dengan berbagai ukuran yaitu 128x85 pixel, 64x85 pixel, 64x43 pixel dan 32x43 pixel, selengkapnya dapat dilihat pada Gambar 2.

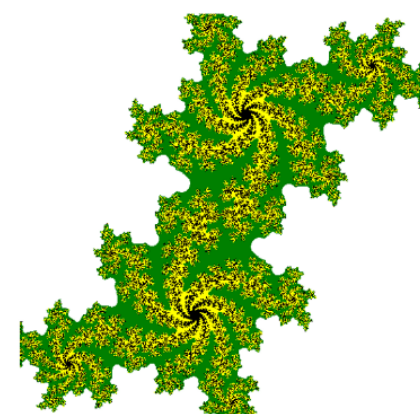

Julia set 1 $c=(-0,10546875,0,626953125)$

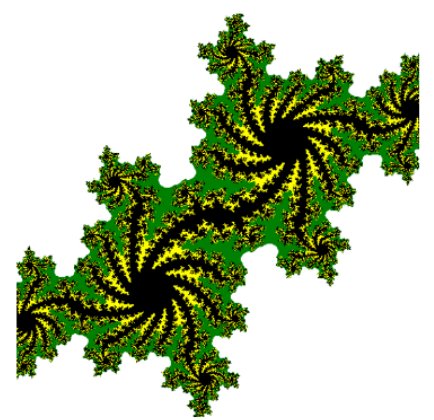

Julia set 2 $c=(0.3041684,0.6353243)$

Gambar 2. Citra Sampul Himpunan Julia untuk beberapa nilai C 


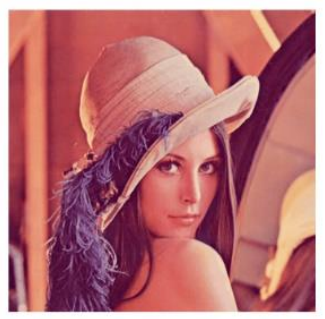

a

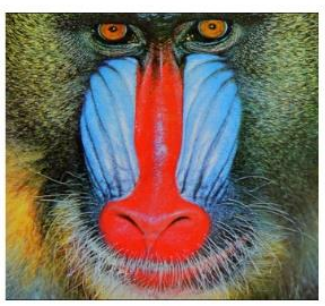

d

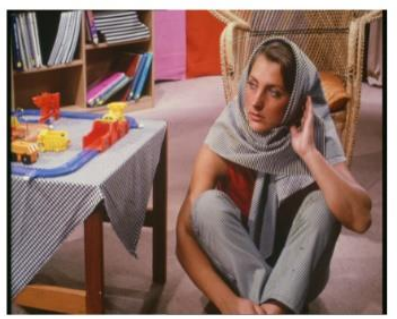

b

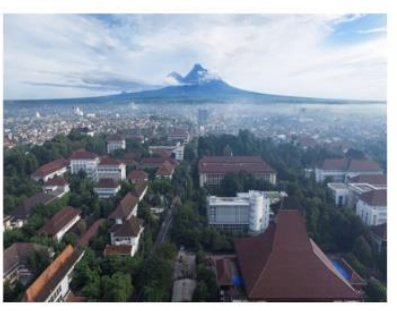

e

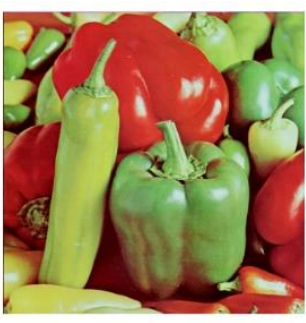

c

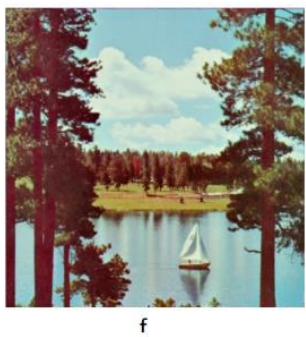

Gambar 3. Beberapa Citra Rahasia serbagai citra uji

\section{B. Algoritme dan Program menyembunyikan dan mengambil citra rahasia pada gambar himpunan Julia.}

Menyembunyikan citra rahasia ke dalam gambar himpunan Julia dengan metode fraktal adalah termasuk steganografi fraktal yaitu teknik menyembunyikan pesan atau informasi dalam suatu citra sampul yang berupa citra fraktal (fractal image) dan memanfaatkan sifat-sifat fraktalnya yaitu antara lain sensitif terhadap nilai awal, kesamaan diri dan iteratif (Agaian dan Susmilch, 2006).

Proses penyembunyian citra rahasia, pertama citra rahasia diubah ke dalam bentuk data biner yaitu berupa matrik yang elemen nya 0 atau 1, kemudian dilakukan pembuatan citra sampul berupa gambar himpunan Julia dari fungsi komplek $\mathrm{z}^{2}-\mathrm{c}$, dengan menggunakan algoritme escape-time yaitu menggunakan iterasi dan pewarnaan berdasarkan nilai-nilai iterasi tertentu $\left(\mathrm{n}_{0}, \mathrm{n}_{1}\right.$ dan $\left.\mathrm{n}_{2}\right)$ dan parameter $\mathrm{R}$ yaitu nilai batas daerah bidang komplek yang keduanya menentukan variasi warnanya, pada penelitian ini digunakan nilai $\mathrm{R}=400$ dan 4 macam warna (hitam, putih, kuning dan hijau), yang dijadikan key pada penelitian ini adalah nilai $\mathrm{c}, \mathrm{n}_{0}, \mathrm{n}_{1}, \mathrm{n}_{2}$ dan ukuran matrik binernya. Proses penyembunyian citra rahasia dilakukan dengan merubah nilai warna RGB (menambah atau mengurangi satu poin) dari pixel citra sampul berdasarkan matrik biner dari citra rahasia didapat citra stego dan key. Sedangkan proses pengambilan citra rahasia dari citra stego dilakukan dengan membuat ulang gambar himpunan Julia berdasarkan key kemudian membandingkannya dengan citra stego didapat matrik biner, kemudian matrik biner diubah menjadi citra rahasia.

Telah dirancang algoritme dan program komputer untuk melakukan penyembunyian dan pengambilan atau ekstraksi citra rahasia menggunakan metode fraktal, dimana citra sampul berupa gambar himpunan Julia yang bisa dicari secara interaktif berdasarkan nilai parameter c dan nilai iterasi $\mathrm{n}$ dan kemudian citra rahasia disembunyikan pada citra sampul menghasilkan citra stego dan citra rahasia dapat diambil Kembali dari citra stego. Program yang dibuat juga menampilkan waktu yang diperlukan untuk melakukan penyembunyian dan pengambilan kembali serta menampilkan nilai parameter kemiripan antara citra sampul dan citra stegonya yaitu RMSE (Root Mean Squared Error) dan PSNR (Peak Signal-to-Noise Ratio).

Algoritme versi delphi untuk membuat citra sampul himpunan Julia :

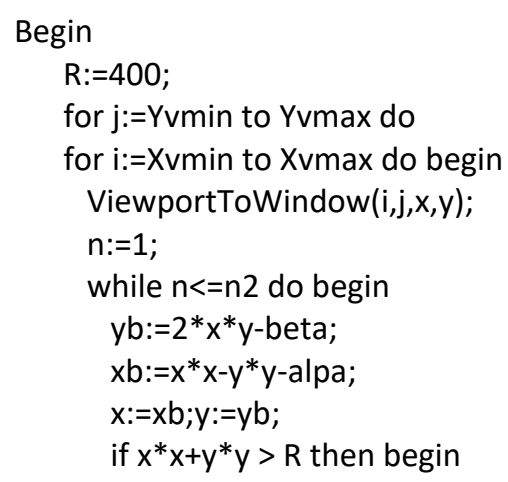




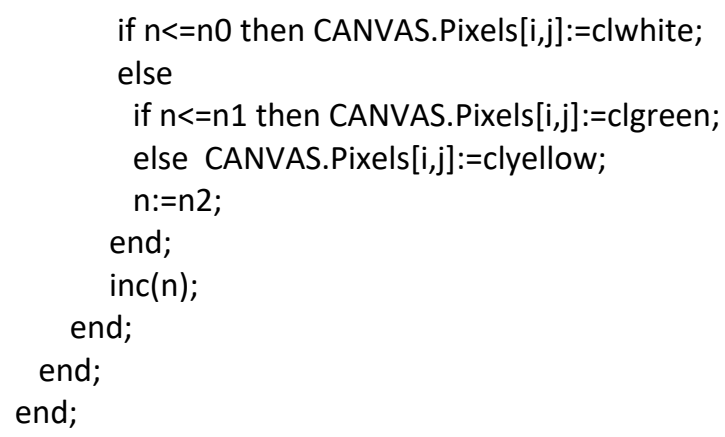

Algoritme versi delphi untuk mengubah citra rahasia menjadi matrik biner 0,1 :

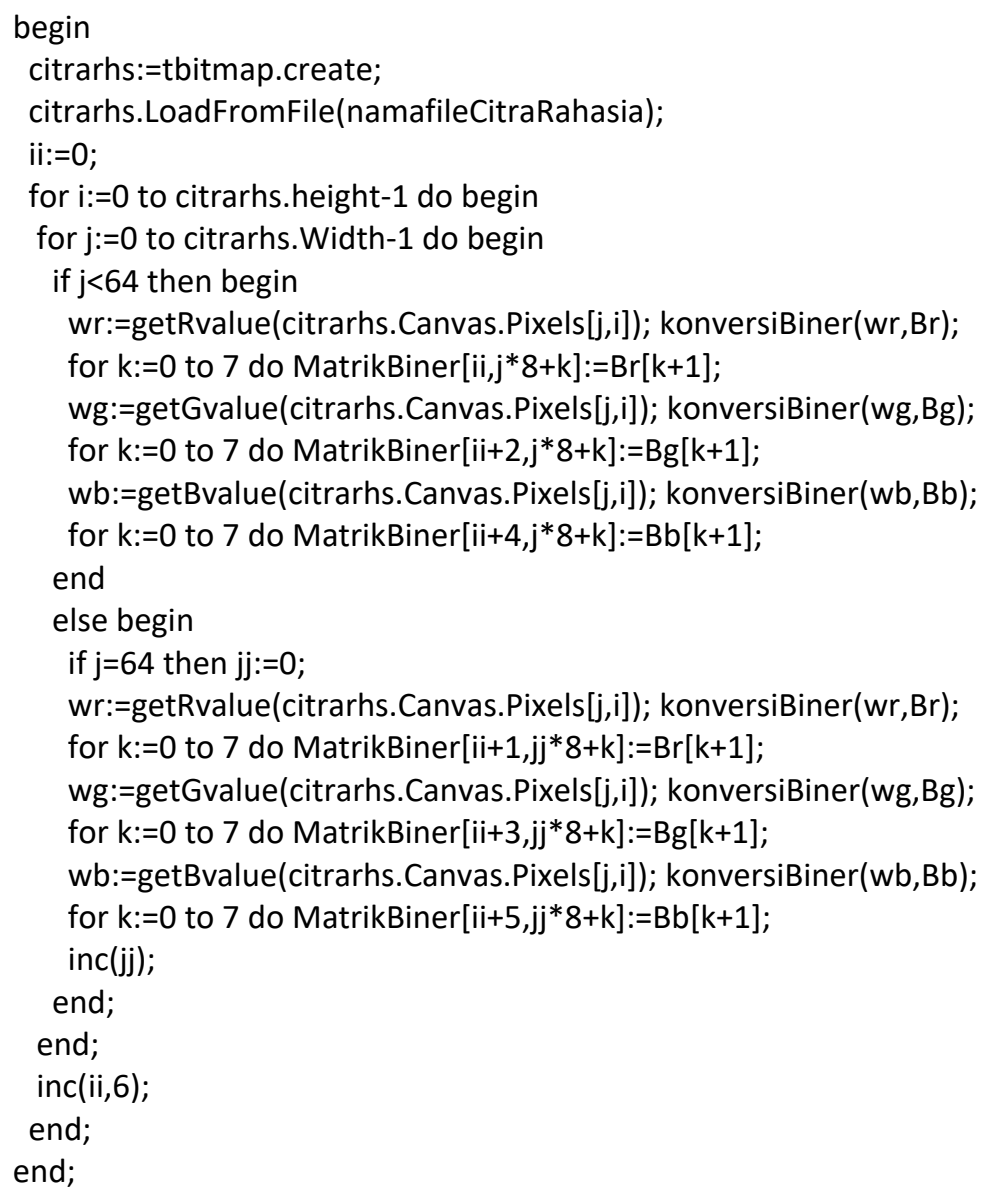

Algoritme versi delphi untuk melakukan penyembunyian citra rahasia adalah sebagai berikut :

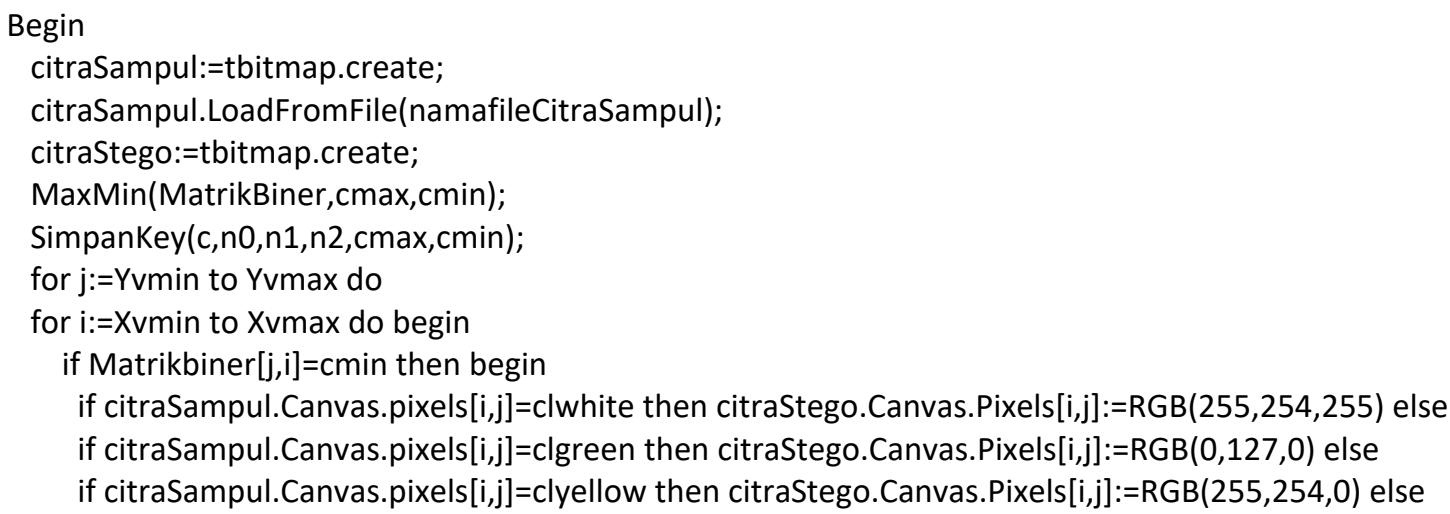




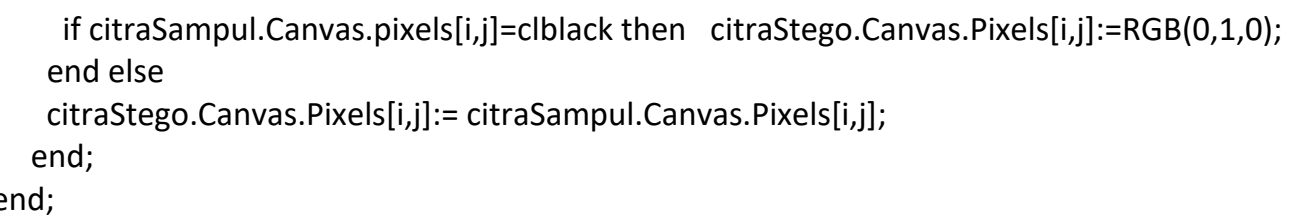

Sedangkan Algoritme versi delphi untuk melakukan pengambilan citra rahasia adalah sebagai berikut :

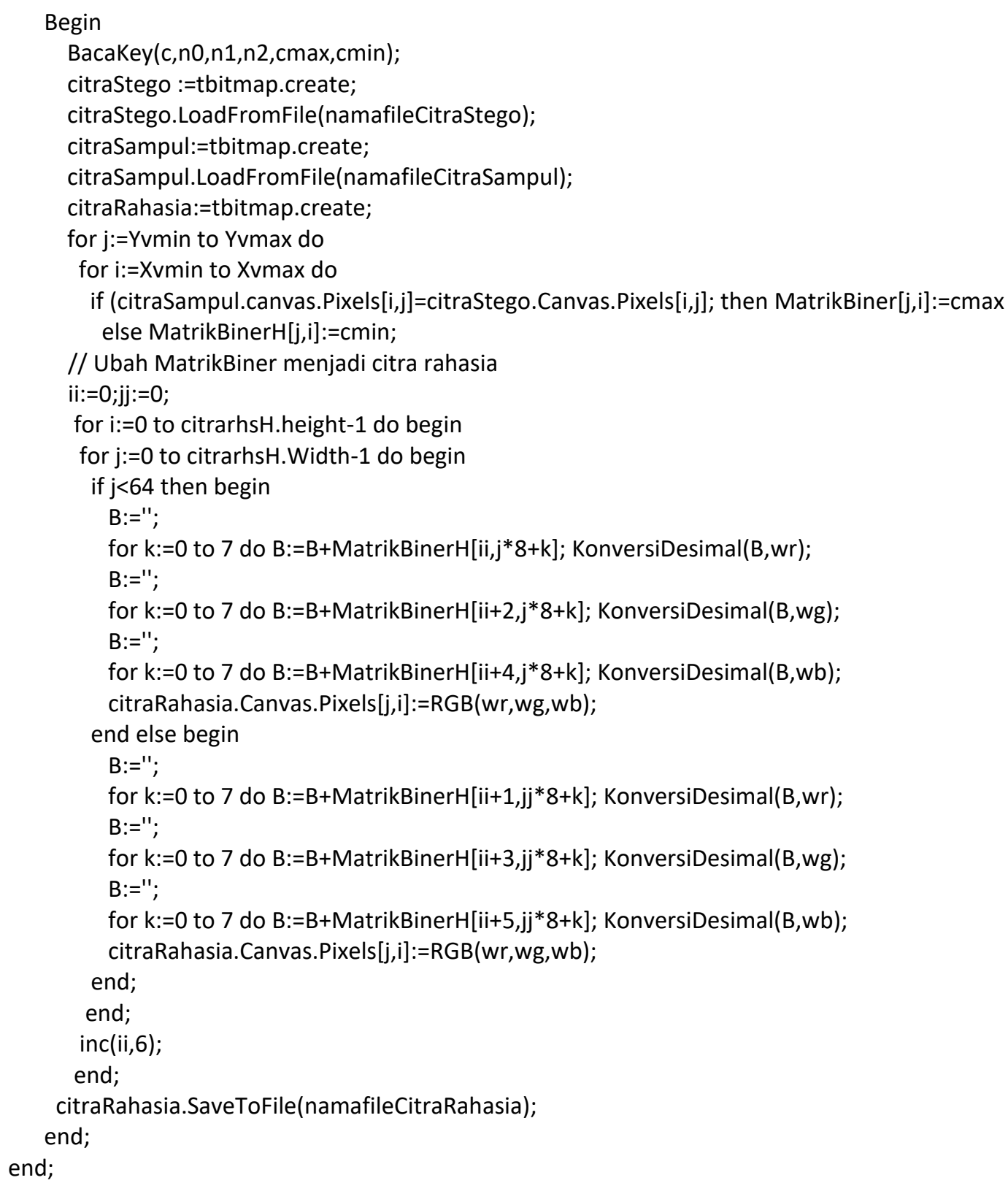

Tampilan dari program yang dibuat hanya terdiri 1 tampilan utama yang mempunyai fasilitas untuk membuat citra sampul, citra stego dan proses ambil citra serta fasilitas lainnya. Tampilan utama program dapat dilihat pada Gambar 3. 


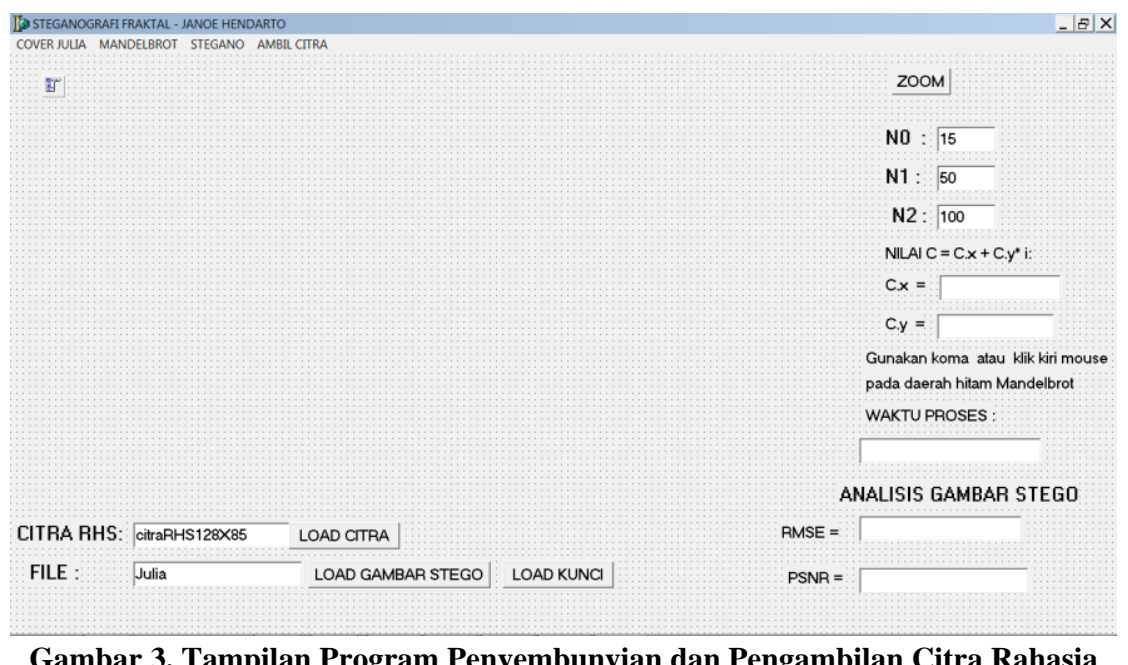

Program dapat membuat berbagai citra sampul dengan menentukan nilai c dan nilai iterasi N0, N1 dan N2. Nilai c menentukan bentuk polanya, dua gambar himpunan Julia yang digunakan dalam penelitian ini dapat dilihat pada Gambar 2 di atas.

\section{Analisis Hasil Program Penyembunyian dan Pengambilan Citra Rahasia}

Untuk mengukur kemiripan dari citra hasil steganografi (citra stego) terhadap citra sampulnya diperlukan parameter PSNR :

$$
\text { PSNR }=20 . \log _{10}(255 / \text { RMSE }) \quad \text { (untuk citra RGB) }
$$$$
\text { dengan RMSE adalah }=\sqrt{\frac{\sum_{0 \leq i \leq m-1 ; 0 \leq j \leq n-1}\left(Z_{i, j}-Y_{i, j}\right)^{2}}{m x n}}
$$

dengan $\mathrm{Z}_{\mathrm{i}, \mathrm{j}}$ nilai warna pixel (i,j) dari citra hasil steganografi dan $\mathrm{Y}_{\mathrm{i}, \mathrm{j}}$ nilai warna pixel $(\mathrm{i}, \mathrm{j})$ dari citra sampul. $\mathrm{m}$ dan $\mathrm{n}$ adalah ukuran lebar dan tinggi citra $(\mathrm{m}=512, \mathrm{n}=512)$.

Nilai RMSE dan PSNR dari hasil program dapat dilihat pada Gambar 4 dan Gambar 5, dari kedua gambar tersebut terlihat bahwa secara visual sulit dibedakan antara citra sampul dan citra stego, kemudian terlihat juga nilai RMSE dan PSNR hampir sama untuk citra rahasia yang berbeda dengan ukuran sama walaupun beda citra sampulnya.

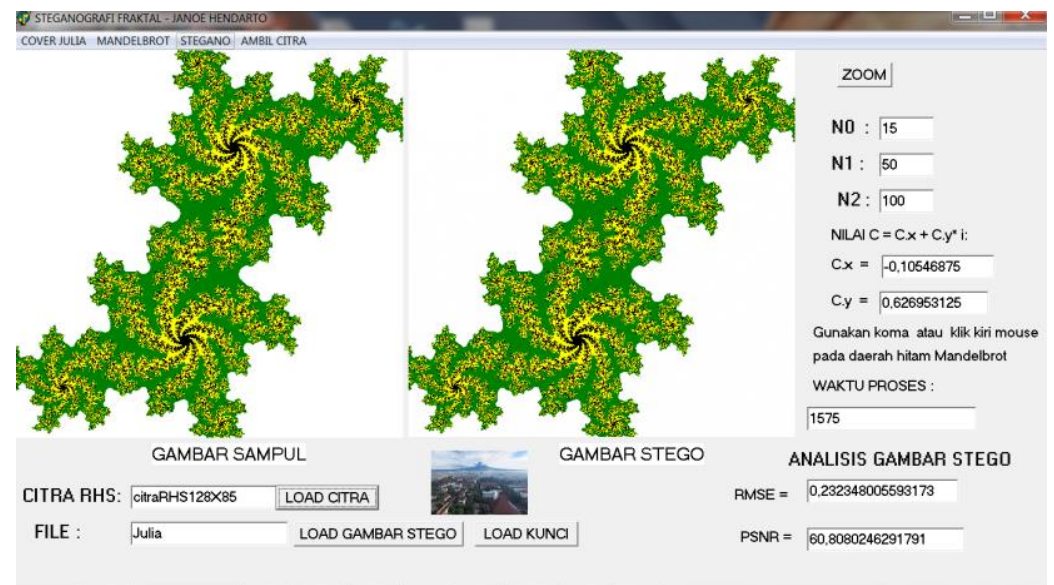

Gambar 4. Hasil Program Penyembunyian Citra UGM pada Citra Sampul Julia Set 1 


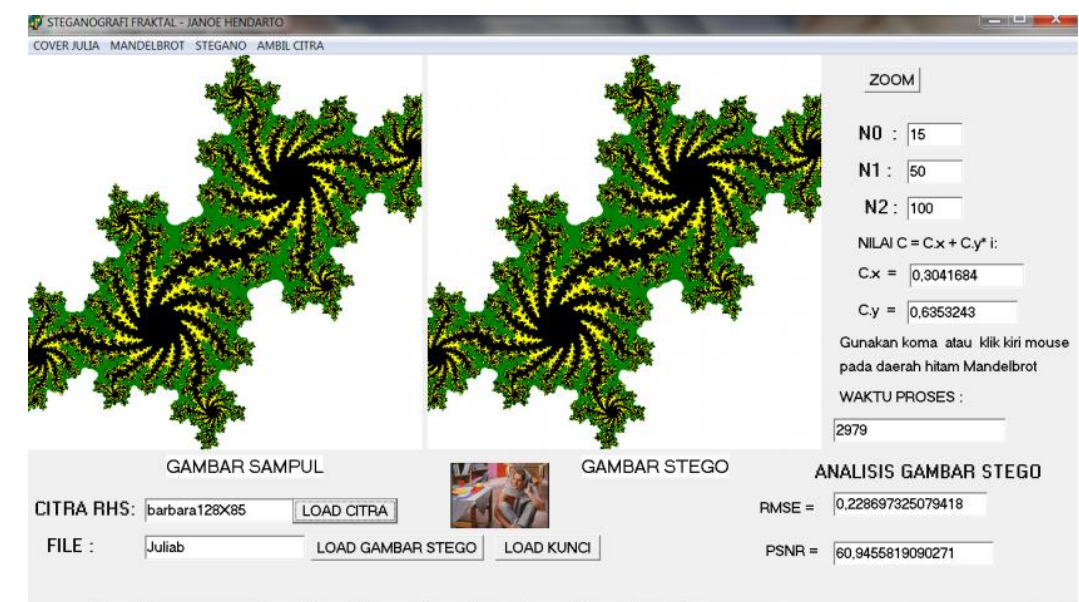

Gambar 5. Hasil Program Penyembunyian Citra Barbara pada Citra Sampul Julia Set 2

Dari beberapa hasil percobaan dengan menggunakan 12 data uji yaitu 6 macam citra rahasia dengan ukuran $128 \times 85$ pixel dan 2 macam citra sampul yaitu himpunan Julia dari fungsi komplek $\mathrm{z}^{2}-\mathrm{c}$ dengan $\mathrm{c}=(-0,10546875$, $0,626953125)$ untuk Julia set 1 dan $c=(0.3041684,0.6353243)$ untuk Julia set 2 dengan ukuran 512 x 512 pixel dan untuk nilai iterasi $\mathrm{n}=15,50$ dan 100, didapat hasil seperti pada tabel 2 . Untuk melihat pengaruh ukuran citra rahasia terhadap kualitas gambar stego dilakukan uji untuk 4 macam ukuran citra rahasia, hasilnya dapat dilihat pada Tabel 3.

Tabel 2. Hasil uji terhadap beberapa citra rahasia dan citra sampul.

\begin{tabular}{|c|c|c|c|c|c|c|}
\hline \multirow[b]{2}{*}{ No. } & \multirow[b]{2}{*}{ Citra RHS } & \multirow[b]{2}{*}{ Citra Sampul } & \multicolumn{2}{|c|}{ Waktu (ms) } & \multirow[b]{2}{*}{ RMSE } & \multirow[b]{2}{*}{ PSNR } \\
\hline & & & Hide & Unhide & & \\
\hline \multirow[t]{2}{*}{1} & Lenna $128 \times 85$ & Julia set 1 & 1.572 & 4.716 & 0,2339 & 60,7504 \\
\hline & & Julia set 2 & 1.667 & 4.307 & 0,2339 & 60,7504 \\
\hline \multirow[t]{2}{*}{2} & Barbara 128x85 & Julia set 1 & 1.552 & 4.746 & 0,2287 & 60,9456 \\
\hline & & Julia set 2 & 1.627 & 4.379 & 0,2287 & 60,9456 \\
\hline \multirow[t]{2}{*}{3} & SaiLBoat $128 \times 85$ & Julia set 1 & 1.627 & 4.678 & 0,2328 & 60,7924 \\
\hline & & Julia set 2 & 1.612 & 4.292 & 0,2328 & 60,7924 \\
\hline \multirow[t]{2}{*}{4} & Pepper $128 \times 85$ & Julia set 1 & 1.606 & 4.773 & 0,2263 & 61,0357 \\
\hline & & Julia set 2 & 1.651 & 4.369 & 0,2263 & 61,0357 \\
\hline \multirow[t]{2}{*}{5} & Baboon 128x85 & Julia set 1 & 1.527 & 4.710 & 0,2290 & 60,9353 \\
\hline & & Julia set 2 & 1.741 & 4.347 & 0,2290 & 60,9353 \\
\hline \multirow[t]{2}{*}{6} & UGM 128x85 & Julia set 1 & 1.648 & 4.670 & 0,2323 & 60,8080 \\
\hline & & Julia set 2 & 1.683 & 4.320 & 0,2323 & 60,8080 \\
\hline \multicolumn{3}{|c|}{ Rata-rata } & 1.626 & 4.526 & 0,2305 & 60,8779 \\
\hline
\end{tabular}

Tabel 3. Hasil uji terhadap beberapa macam ukuran citra rahasia

\begin{tabular}{|c|c|c|c|c|c|c|}
\hline & & & \multicolumn{2}{|c|}{ Waktu $(\mathbf{m s})$} & \multirow{2}{*}{} & \multirow{2}{*}{ No. } \\
\cline { 4 - 5 } Citra RHS & Jumlah bits & Hide & UnHide & RMSE & PSNR \\
\hline 1 & Lenna 128x85 & 261.120 & 1.572 & 4.716 & 0,2339 & 60,7504 \\
\hline 2 & Lenna 64x85 & 130.560 & 1.342 & 4.524 & 0,1658 & 63,7393 \\
\hline 3 & Lenna 64x43 & 66.048 & 1.248 & 4.431 & 0,1180 & 66,6953 \\
\hline 4 & Lenna 32x43 & 33.024 & 1.233 & 4.400 & 0,0831 & 69,7378 \\
\hline
\end{tabular}


Dari tabel 2 di atas, terlihat bahwa nilai rata-rata RMSE adalah 0,2305, sedangkan nilai rata-rata PSNR adalah 60,8779, hal ini menunjukkan bahwa citra stego hasil penyembunyian citra rahasia tidak berbeda jauh dengan citra sampul, secara visual tidak dapat dilihat perbedaannya, dan juga terlihat bahwa nilai RMSE dan PSNR sama untuk citra sampul yang berbeda. Waktu proses penyembunyian citra rahasia (Hide) rata-rata 1,626 detik (tidak termasuk waktu pembuatan citra sampul) sedangkan waktu proses pengambilan kembali citra rahasia (UnHide) rata-rata 4,526 detik. Dari Tabel 3 di atas, terlihat waktu yang diperlukan untuk proses penyembunyian dan pengambilan citra rahasia sedikit berpengaruh terhadap ukuran citra rahasia, sedangkan untuk RMSE dan PSNR (mengukur kualitas citra stego) sangat berpengaruh terhadap ukuran citra rahasia, semakin kecil ukuran citra rahasia semakin kecil RMSEnya dan semakin besar PSNRnya.

\section{KESIMPULAN}

Dari penelitian yang dilakukan dapat ditarik beberapa kesimpulan sebagai berikut :

1. Telah berhasil disusun algoritme dan program untuk melakukan penyembunyian dan pengambilan citra rahasia pada gambar Himpunan Julia $\mathrm{z}^{2}-\mathrm{c}$.

2. Program yang dibuat dapat melakukan pemilihan gambar himpunan Julia sebagai gambar sampul sekaligus membuat kunci (nilai c), kemudian dapat melakukan penyembunyian dan pengambilan citra rahasia

3. Ukuran citra rahasia yang dapat disembunyikan bergantung pada ukuran gambar sampulnya, untuk ukuran gambar sampul 512x512 (262144 pixel) dapat disembunyikan citra rahasia 24 bit warna berukuran maksimal $128 \times 85$ (261120 bit ).

4. Citra stego diukur terhadap citra sampul, untuk 6 macam citra rahasia dengan ukuran maksimal dan 2 macam citra sampul, didapat nilai rata-rata PSNR adalah 60,8779 dengan rata-rata RMSE adalah 0,2305 dan kedua nilai tersebut dipengaruhi oleh ukuran citra rahasianya, sedangkan macam citra sampul tidak mempengaruhi nilai RMSE dan PSNR. Waktu proses penyembunyian (Hide) rata-rata 1.626 detik sedangkan waktu proses pengambilan (UnHide) rata-rata 4.526 detik.

\section{DAFTAR PUSTAKA}

[1]. Agaian, S.S. dan Susmilch, J.M., 2006, "Fractal Steganography Using Artificially Generated Images", pp. 312-317, 1-4244-0359-6/06/\$20.00 @2006 IEEE.

[2]. Gupta, R. dkk., 2018, “ Digital Image Encoding Scheme using Fractal Approach “, 978-1-5386-26153/18/\$31.00@2018 IEEE.

[3]. Hendarto, J., 2019, "Steganografi Menggunakan Citra Fraktal Himpunan Julia”, ISSN: 2548-8082 Jurnal PRODUKTIF Vol 3 No.2 Edisi Desember 2019.

[4]. Hosam, O., 2018, "Hiding Bitcoins in Steganographic Fractals”, pp. 512-519, 978-1-5386-7568-7/18/\$31.00 (C)2018 IEEE.

[5]. Kaur, G. dan Verma, S.K., 2018, "Multi- Level Secured Encryption Technique Using Enhanced Fractal Image Watermarking”,pp. 314-322, 978-1-5386-2456-2/18/\$31.00 @2018 IEEE.

[6]. Kiani, K. dan Soleimani, M.A.V., 2010, "Image Authentication Using Fractal Watermarking and Chaos Theory”, 978-1-4244-7907-8/10/\$26.00 @2010 IEEE.

[7]. Mohammed, N.Q. dkk., 2018, "Suitability of Using Julia Set Images as a Cover for Hiding Information”, pp. 71-74, 978-1-5386-8452-8/18/\$31.00 (C2018 IEEE.

[8]. Patel, H.N. dkk., 2017 ,'Design of a Color Palette Based Image Steganography Algorithm for Fractal Images", pp.2584-2589, 978-1-5090-4442-9/17/\$31.00_c 2017 IEEE.

[9]. Zhang, H. dkk.,2011,“A Steganography Scheme Based on Fractal Images”, 2011 Second International Conference on Networking and Distributed Computing, pp. 28-31, 978-0-7695-4427-4/11 \$26.00 (C) 2011 IEEE.

\section{Biodata Penulis}

Drs. Janoe Hendarto M.Kom., memperoleh gelar Sarjana Matematika (Drs.), Program Studi Matematika FMIPA UGM, lulus tahun 1986. Tahun 1992 memperoleh gelar Magister Komputer (M.Kom) dari Program Studi Ilmu Komputer Program Pascasarjana UI. Saat ini sebagai Staf Pengajar program studi S1 Ilmu Komputer Departemen Ilmu Komputer dan Elektronika FMIPA Universitas Gadjah Mada. 